\title{
Lower BAFF Levels in Myasthenic Patients Treated with Glucocorticoids
}

\author{
Ewa Sobieszczuk ${ }^{1}$. Piotr Szczudlik ${ }^{1}$ - Justyna Kubiszewska ${ }^{1}$ - Beata Szyluk ${ }^{1}$ - Marta Lipowska ${ }^{1}$. \\ Małgorzata Dutkiewicz ${ }^{2} \cdot$ Anna Kostera-Pruszczyk $^{1}$
}

Received: 3 March 2021 / Accepted: 6 July 2021 / Published online: 2 August 2021

(c) The Author(s) 2021

\begin{abstract}
B-cell activating factor (BAFF), a member of tumor necrosis factor family, activates B cells, promotes their survival and proliferation. BAFF is considered to have an influence on development of autoimmune diseases including myasthenia gravis (MG). We aimed to evaluate BAFF serum levels in MG patients, their potential connection with therapy and course of MG. Cross-sectional study. Two hundred eighteen adult patients with MG (67\% women, age: $18-89$ years, $82.6 \%$ AChR antibody seropositive $(\operatorname{AChRAb}(+))$. Serum BAFF levels, their relationship with severity of clinical symptoms, therapy conducted, clinical and demographic features and other factors were analyzed. Patients with $\mathrm{AChRAb}(+) \mathrm{MG}$ demonstrated significantly higher BAFF levels than MuSK-MG patients $(831.2 \pm 285.4 \mathrm{pg} / \mathrm{ml}$ vs. $745.6 \pm 633.4 \mathrm{pg} / \mathrm{ml}$, respectively; $p=0.030)$. Serum BAFF levels in women were significantly higher than in men $(855.9 \pm 302.5$ vs. $756.6 \pm 289.4$, respectively; $p=0.017)$. Mean serum BAFF level was significantly decreased in patients who were ever treated with corticosteroids (CS) (770.4 $\pm 327.8 \mathrm{pg} /$ $\mathrm{ml}$ vs. $891.3 \pm 246.1 \mathrm{pg} / \mathrm{ml}$, respectively; $p=0.001)$. Thymoma-MG patients demonstrated significantly lower BAFF levels $(671.2 \pm 244.9$ vs. $833.5 \pm 302.4$, respectively; $p=0.044)$. Thymectomized patients did not differ in BAFF levels from the MG patients who had not undergone thymectomy. In multiple linear regression model, recent CS therapy and male sex were found to be independent predictors of lower BAFF levels. Serum BAFF level is decreased in patients treated with CS, which may suggest inhibiting influence of $\mathrm{CS}$ on BAFF-a potential mechanism contributing to the effectiveness of such therapy.
\end{abstract}

Keywords Myasthenia gravis $\cdot$ BAFF $\cdot$ B-cell activating factor $\cdot$ Glucocorticoids $\cdot$ MG $\cdot$ Cytokine

\section{Introduction}

B-cell activating factor (BAFF) belongs to tumor necrosis factor (TNF) family and is a crucial factor for development and survival of B lymphocytes. Several of its numerous roles include modifying of pro- and anti-apoptotic signals, initiating change for B class lymphocytes, inducing proliferation and secretion of T-cell response cytokines. Binding BAFF to its receptor on $B$ cells results in stimulation of B cells and promotes antibody production by several different mechanisms, increasing B cells survival and proliferation also with blockade of self-reactive B cells. BAFF was confirmed to be one of key factors in promoting autoimmunity (Khan

Piotr Szczudlik

pszczudlik@wum.edu.pl

1 Department of Neurology, Medical University of Warsaw, Banacha 1a, 02-097 Warsaw, Poland

2 Department of Immunology, Biochemistry and Nutrition, Medical University of Warsaw, Warsaw, Poland et al. 2013; Lahiri et al. 2012; Moore et al. 1999; Pillai et al. 2011). Its elevated serum levels have been demonstrated in myasthenia gravis (MG), lupus erythematosus, rheumatoid arthritis, Sjogren's syndrome, autoimmune hepatitis, primary biliary cirrhosis and Graves' disease (Chen et al. 2014; Kang et al. 2016; Kim et al. 2008; Migita et al. 2010; Vannucchi et al. 2012).

Myasthenia gravis is an autoimmune disorder of neuromuscular junction marked by skeletal muscle weakness and fatigability. In almost $90 \%$ of patients, it is caused by circulating antibodies against acetylcholine receptors (AChR); MuSK autoantibodies are present in approximately $5 \%$ of MG patients (Hoch et al. 2001; Lindstrom et al. 1976). MG can co-exist with various autoimmune diseases, most frequently $(26.8 \%)$ with autoimmune thyroid diseases (Kubiszewska et al. 2016). It is typically treated with acetylcholinesterase inhibitors and immunosuppressants, and, in selected cases, with thymectomy. Higher serum BAFF levels in MG patients in comparison with healthy controls have been already reported (Kang et al. 2016; Kim et al. 
2008; Ragheb et al. 2008; Scuderi et al. 2011). It prompted us to evaluate possible relationship of BAFF with the type of treatment and other factors within specific subgroups of MG patients.

\section{Patients and Methods}

\section{Subjects}

Two hundred eighteen adult patients with MG were enrolled in this study. Clinical diagnosis of MG was confirmed by positive result of repetitive nerve stimulation test or SFEMG and/or serum anti-AChR or anti-MuSK antibodies levels. $67 \%$ of tested patients were women; age ranged $18-89$ years; $82.6 \%$ of subjects were seropositive for AChR antibodies $(\mathrm{AChRAb}(+)) .56 .4 \%$ of patients were classified as earlyonset MG (EOMG; $\leq 50$ years), $37.2 \%$ as late-onset MG (LOMG; $>50$ years); 6.4\% had thymoma-MG (T-MG). Majority (56.4\%) of the subjects have ever received corticosteroids (CS) therapy, $46.3 \%$ were treated with CS within last three months. $42.7 \%$ of all patients underwent thymectomy. The severity of symptoms was assessed with Myasthenia Gravis Foundation of America clinical classification scale (MGFA Classification). Results of treatment were assessed according to the MGFA Post-Intervention Status scale. Demographic, clinical and treatment of MG patients were summarized in Table 1.

\section{Methods}

BAFF serum levels were measured in duplicate by ELISA (Human BAFF/BLyS/TNFSF13B Immunoassay, Quantikine ELISA, R\&D Systems cat. no DBLYSOB) according to the manufacturer's instruction.

\section{Statistical Analysis}

All continuous data were expressed as means and standard deviations (SDs). To test distribution of continuous variables, we used Kolmogorov-Smirnov or Shapiro-Wilk tests according to the size of different subgroups. The Student's $t$ test and Mann-Whitney test were used to compare continuous variables between two groups as appropriate. Differences between more than two groups were tested using ANOVA with Bonferroni post hoc tests and Kruskal-Wallis test with post hoc multiple comparisons (all pairwise) as appropriate. Correlations were assessed using Pearson's correlation coefficients or Spearman's correlation coefficients according to the data distribution. To test interactions
Table 1 Demographic, clinical and treatment of MG patients

\begin{tabular}{|c|c|}
\hline Variable & Value \\
\hline \multicolumn{2}{|l|}{ Gender (number of patients) } \\
\hline Male & $72(33 \%)$ \\
\hline Female & $146(67 \%)$ \\
\hline \multicolumn{2}{|l|}{ Current age (years) } \\
\hline Mean \pm SD & $51.3 \pm 18.7$ years \\
\hline \multicolumn{2}{|l|}{ Disease duration (years) } \\
\hline Mean \pm SD & $9.2 \pm 9.0$ years \\
\hline \multicolumn{2}{|l|}{ Age of onset (years) } \\
\hline Mean \pm SD & $42.5 \pm 22.0$ years \\
\hline \multicolumn{2}{|c|}{ Type of MG (number of patients) } \\
\hline EOMG & $123(56.4 \%)$ \\
\hline LOMG & $81(37.2 \%)$ \\
\hline T-MG & $14(6.4 \%)$ \\
\hline \multicolumn{2}{|c|}{ Serological status (number of patients) } \\
\hline $\operatorname{AChRAb}(+)$ & $180(82.6 \%)$ \\
\hline $\operatorname{MuSK}(+)$ & $9(4.1 \%)$ \\
\hline $\operatorname{AChRAb}(-), \operatorname{MuSK}(-)$ & $29(13.3 \%)$ \\
\hline \multicolumn{2}{|c|}{ MGFA score (number of patients) } \\
\hline 0 & $46(21.1 \%)$ \\
\hline I & $37(17.0 \%)$ \\
\hline II & $112(51.4 \%)$ \\
\hline III & $20(9.2 \%)$ \\
\hline IV & $3(1.4 \%)$ \\
\hline \multicolumn{2}{|c|}{ Post-intervention status (number of patients) } \\
\hline Remission & $14(6.4 \%)$ \\
\hline Pharmacologic remission & $42(19.3 \%)$ \\
\hline Improvement & $123(56.4 \%)$ \\
\hline No improvement & $20(9.2 \%)$ \\
\hline Worsening & $16(7.3 \%)$ \\
\hline No data & $3(1.4 \%)$ \\
\hline \multicolumn{2}{|c|}{ Treatment within last 3 months (number of patients) } \\
\hline AChE inhibitors only & $113(51.8 \%)$ \\
\hline Glucocorticoids & $67(30.7 \%)$ \\
\hline Other immunosuppression & $4(1.8 \%)$ \\
\hline $\mathrm{IS}+\mathrm{CS}$ & $34(15.6 \%)$ \\
\hline \multicolumn{2}{|c|}{ Glucocorticoids in the past (number of patients) } \\
\hline Yes & $123(56.4 \%)$ \\
\hline No & $95(43.6 \%)$ \\
\hline \multicolumn{2}{|c|}{ Thymectomy (number of patients) } \\
\hline Yes & $93(42.7 \%)$ \\
\hline No & $120(55.0 \%)$ \\
\hline No data & $5(2.3 \%)$ \\
\hline
\end{tabular}

among variables, multivariate linear regression analysis was applied, including all variables from univariate models with the minimum significance level of 0.05 . For the statistical analysis, SPSS version 20.0 was used. 


\section{Results}

Patients with AChRAb(+) MG demonstrated significantly higher BAFF levels than MuSK-MG patients $(831.2 \pm 285.4 \mathrm{pg} / \mathrm{ml}$ vs. $745.6 \pm 633.4 \mathrm{pg} / \mathrm{ml}$, respectively; $p=0.030$ ). Mean serum BAFF level was significantly decreased in patients who have ever received CS as compared with the remaining group $(770.4 \pm 327.8 \mathrm{pg} /$ $\mathrm{ml}$ vs. $891.3 \pm 246.1 \mathrm{pg} / \mathrm{ml}$, respectively; $p=0.001)$. Serum BAFF levels in patients treated with CS within last three months were significantly decreased in comparison with those who have not received such therapy recently $(723.8 \pm 329.2 \mathrm{pg} / \mathrm{ml}$ vs. $914.6 \pm 243.5 \mathrm{pg} / \mathrm{ml}$, respectively; $p<0.001)$. We have performed analysis depending on serological status; for $\mathrm{AChRAb}(+) \mathrm{MG}$ patients treated with CS within last three months, mean BAFF levels were $730.5 \pm 295.8$ vs. $930.7 \pm 239.5$ for untreated $(p \leq 0.001)$; for patients treated with CS whenever in the past, mean BAFF levels amounted $778.8 \pm 301.0 \mathrm{vs}$. $907.8 \pm 243.0 \mathrm{pg} / \mathrm{ml}$ for untreated $(p=0.002)$. We have also found such differences within AChRAb(-)MuSK(-) MG patients: those treated with CS within last three months as well as patients treated with CS whenever in the past showed significantly lower BAFF levels in comparison with untreated $(613.97 \pm 127.7 \mathrm{pg} / \mathrm{ml}$ vs. $855.4 \pm 258.6 \mathrm{pg} / \mathrm{ml}$, respectively; $p=0.009 ; 626.6 \pm 147.9$ vs. $873.9 \pm 257.2 \mathrm{pg} /$ $\mathrm{ml}$, respectively; $p=0.006$ ). Patients using other than CS immunosuppressants (IS) had no statistically significant difference in BAFF levels in comparison with patients without CS and/or other IS therapy $(860.3 \pm 274.7 \mathrm{pg} / \mathrm{ml}$ IS vs. $910.6 \pm 245.6 \mathrm{pg} / \mathrm{ml}$ no IS; $p=0.481)$ There were also no differences between subgroups taking CS only vs. CS plus other IS $(p=0.468)$. BAFF did not correlate with AChRAb or anti-MuSK antibodies levels. T-MG patients demonstrated significantly lower BAFF levels than the nonT-MG (respectively $671.2 \pm 244.9$ vs. $833.5 \pm 302.4 \mathrm{pg} / \mathrm{ml}$; $p=0.044)$. There were also no differences in BAFF levels between T-MG patients treated with CS recently or in the past vs. untreated ( $p=0.243)$. Thymectomy in the past had no influence on BAFF levels $(p=0.426)$. BAFF levels were significantly higher in women $(855.9 \pm 302.5 \mathrm{pg} / \mathrm{ml}$ vs. $756.6 \pm 289.4$, respectively; $p=0.017$ ), but they were not correlated with the age of patient or the age of onset. Severity of MG symptoms considered as MGFA score was negatively correlated to the BAFF level $(p=0.005)$, but it was dependent on the use of CS within last three months. Within group of patients in remission, serum BAFF levels did not significantly differ from those with active form of disease $(p=0.14)$. There was no statistically significant difference in BAFF levels between EOMG and LOMG patients $(p=0.756)$; we also did not find any differences depending on MGFA Post-Intervention Status $(p=0.325)$. Results of comparison of BAFF levels between subgroups
Table 2 Results of comparison of BAFF levels between subgroups of MG patients

\begin{tabular}{lccc}
\hline & \multicolumn{2}{c}{ BAFF $(\mathrm{pg} / \mathrm{ml})$} & Significance \\
\cline { 2 - 3 } & Mean & SD & \\
\hline CS therapy within last 3 months & & $<0.001$ \\
Yes & 723.8 & 329.2 & \\
No & 914.6 & 243.5 & \\
CS therapy in the past & & & 0.001 \\
Yes & 770.4 & 327.8 & \\
No & 891.3 & 246.1 & 0.017 \\
Gender & & & \\
Women & 855.9 & 302.5 & \\
Men & 756.6 & 289.4 & 0.044 \\
Thymoma & & & \\
Yes & 671.2 & 244.9 & 0.030 \\
No & 833.5 & 302.4 & \\
Serological status & & & \\
AchRAb(+) & 831.2 & 285.4 & \\
MuSK(+) & 745.6 & 633.4 & \\
\hline
\end{tabular}

Table 3 Multivariate linear regression model

\begin{tabular}{|c|c|c|c|c|c|}
\hline & \multicolumn{2}{|c|}{$\begin{array}{l}\text { Unstandardized } \\
\text { coefficients }\end{array}$} & \multirow{2}{*}{$\begin{array}{l}\text { Standard- } \\
\text { ized coef- } \\
\text { ficients } \\
\text { Beta }\end{array}$} & \multirow[t]{2}{*}{$t$} & \multirow[t]{2}{*}{ Significance } \\
\hline & $B$ & SE & & & \\
\hline (Constant) & 1127.500 & 82.943 & & 13.594 & 0.000 \\
\hline $\begin{array}{l}\text { Treatment } \\
\text { with CS } \\
\text { within last } \\
3 \text { months }\end{array}$ & -140.592 & 48.979 & -0.233 & -2.870 & 0.005 \\
\hline $\begin{array}{l}\text { Thymoma- } \\
\text { MG }\end{array}$ & -91.713 & 79.750 & -0.075 & -1.150 & 0.251 \\
\hline $\begin{array}{l}\text { Treatment } \\
\text { with CS in } \\
\text { the past }\end{array}$ & -32.826 & 47.863 & -0.054 & -0.686 & 0.494 \\
\hline $\begin{array}{r}\text { MGFA } \\
\text { score }\end{array}$ & -37.668 & 20.394 & -0.122 & -1.847 & 0.066 \\
\hline $\begin{array}{l}\text { Male gen- } \\
\text { der }\end{array}$ & -87.661 & 41.815 & -0.137 & -2.096 & 0.037 \\
\hline$R=0.369 ; R$ & $=0.136$ & usted & $=0.116$ & 0.000 & \\
\hline
\end{tabular}

$P$-values marked with bold indicate statistically significant $p$-values

Predictors of BAFF levels

of MG patients are summarized in Table 2. In multivariate linear regression analysis, independent predictors of lower BAFF levels were: recent treatment of CS and male sex (Table 3). Figure 1A-D presents differences in BAFF levels depending on the serological status of non-T-MG patients $(1 \mathrm{~A})$, presence of thymoma (1B), treatment with prednisone within last three months in T-MG vs. non-TMG patients (1C) and treatment with CS in the past (1D). 

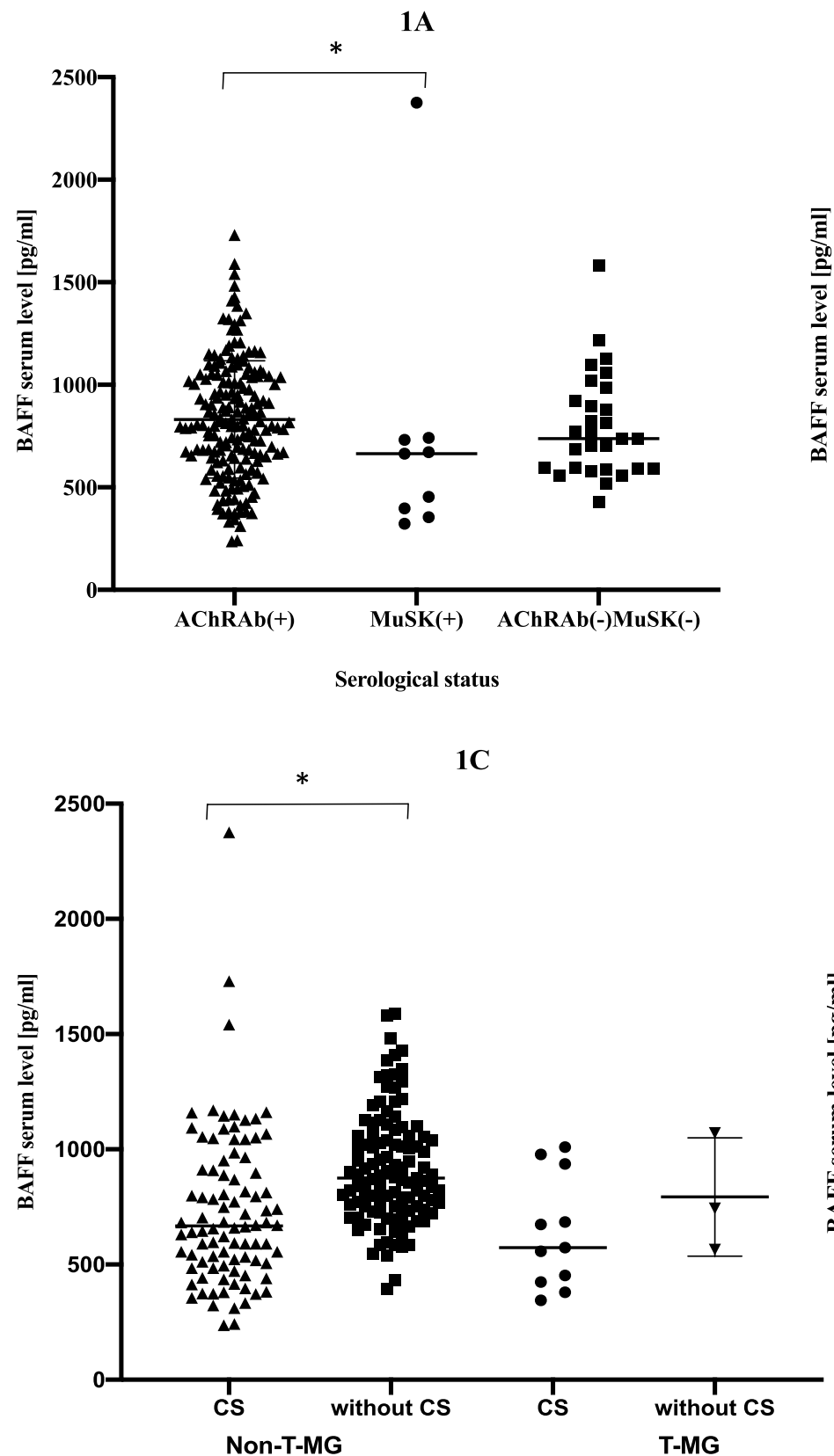
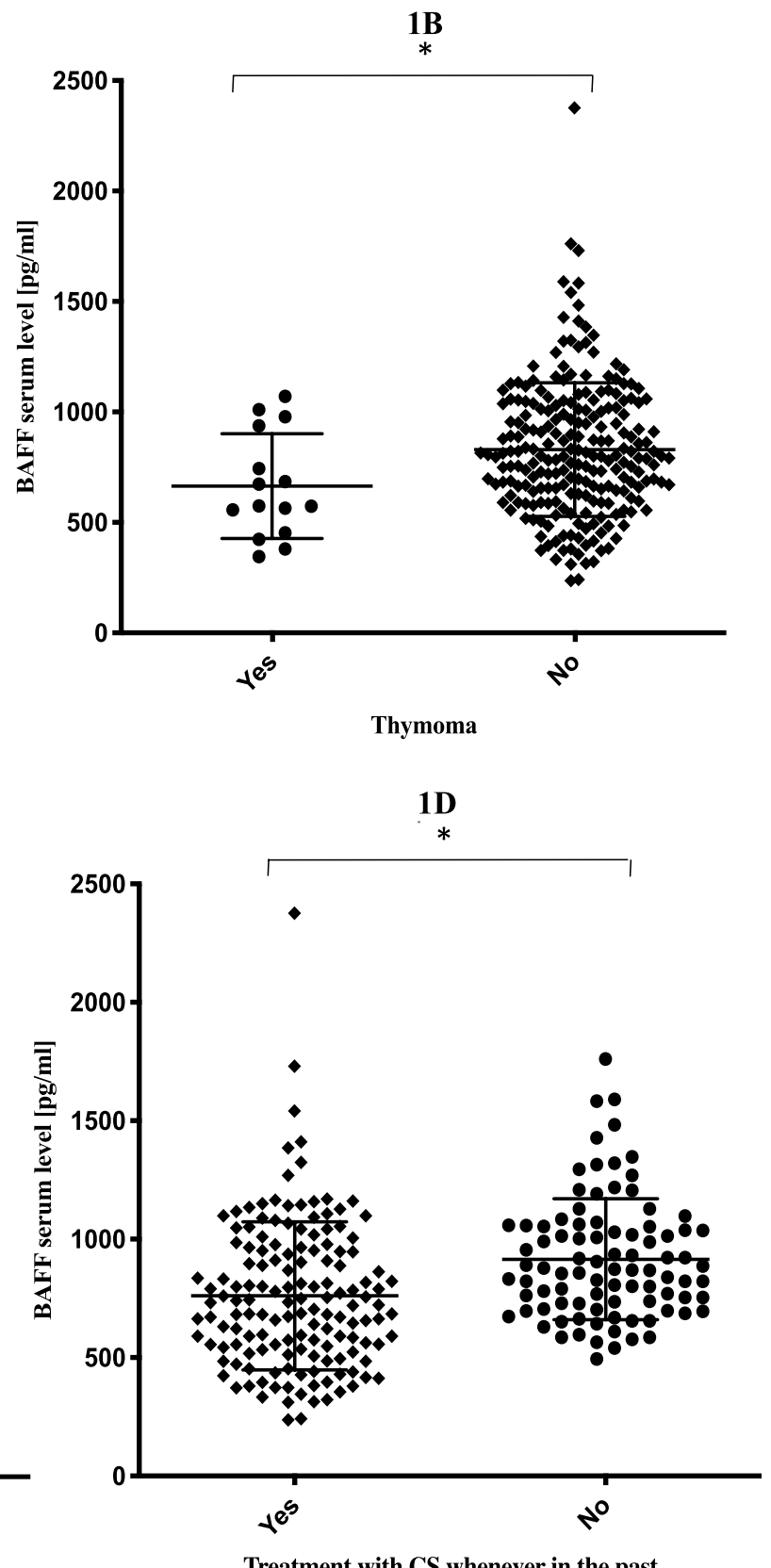

Fig. 1 A Differences in BAFF serum levels depending on serological status of non-thymoma MG patients; $\mathbf{B}$ differences in BAFF serum levels between thymoma and non-thymoma MG patients; $\mathbf{C}$ differences in BAFF serum levels depending on treatment with CS within

Detailed data on BAFF serum levels and MGFA status of patients are provided in supplementary material (Table S1).

\section{Discussion}

Since its discovery in 1999 (Schneider et al. 1999), the role of BAFF in autoimmunity has been widely proved (Chen et al. 2014; Ferraccioli and Gremese 2017; Lahiri last three-month status in seropositive MG patient; $\mathbf{D}$ differences in BAFF serum levels depending on treatment with CS status in study cohort. Non-T-MG non-thymoma-MG, $T-M G$ thymoma MG, $C S$ corticosteroids; $* p<0.05$

et al. 2012; Pillai et al. 2011). It has been reported that serum BAFF levels are increased in many autoimmune disorders, including MG (Kang et al. 2016; Kim et al. 2008; Migita et al. 2010; Ragheb et al. 2008; Scuderi et al. 2011; Thangarajh et al. 2006; Vannucchi et al. 2012). Mechanisms of BAFF have been described by several research groups (Chen et al. 2014; Hu et al. 2019; Kalled 2005; Khan et al. 2013; Pillai et al. 2011; Qin et al. 2011; Rauch et al. 2009; Schneider et al. 1999; Swee et al. 2010; Tang 
et al. 2018). This study has tested the potential connection between serum BAFF levels and laboratory or clinical features, type of MG, type of treatment and other factors.

We have observed significantly higher BAFF levels in patients with AChRAb(+) MG in comparison with MuSKMG, although, as in previous reports, our MuSK-MG group was small (Guptill et al. 2015; Ragheb et al. 2008). It was already described that $\mathrm{AChRAb}(+) \mathrm{MG}$ patients have BAFF levels higher than healthy controls (Kang et al. 2016). Also MuSK-MG patients were reported to have higher BAFF levels than healthy individuals (Guptill et al. 2015), while to our knowledge, there were no differences between $\mathrm{AChRAb}(+)$ and MuSK-MG patients described as seen in our material. Trend towards higher BAFF levels in $\mathrm{AChRAb}(+) \mathrm{MG}$ patients was observed in Ragheb et al. (2008) and Kim et al. (2008) studies, but it did not reach the statistical significance, possibly due to the sample size.

We have demonstrated significant decrease in BAFF levels in patients treated with CS within last three months; this relationship was seen also when CS were used at any time in the past in comparison with patients never treated with CS. Not only $\operatorname{AChRAb}(+)$, but also AChRAb(-)MuSK(-) MG patients had lower BAFF levels when treated with CS therapy. Only one MuSK-MG patient was not treated with CS, though we were not able to perform proper analysis within this subgroup. Lowering BAFF as the possible result of CS therapy has been already observed and reported in Kang et al. (2016) and Scuderi et al. (2011) studies, but Kim et al. (2008) did not demonstrate such differences. All previous studies reported the influence of current CS use only and did not describe differences in subgroups depending on serological status. Although we demonstrated that BAFF levels are higher in $\mathrm{AChRAb}(+)$ than MuSK-MG, we were not able to evaluate if there were any differences in BAFF levels depending on CS treatment status in MuSK-MG patients, as their number was small. Our data confirm that BAFF is decreased in patients using CS; the question remains how long-lasting this effect is, and whether CS's potential influence on BAFF level parallels changes in clinical status of the patient.

We did not see differences in BAFF levels depending on any IS treatment other than CS. This could indicate that various pathways are responsible for efficacy of IS than CS in MG.

Similarly to Ragheb et al. (2008), we did not find any correlation between BAFF and AChRAb levels. Such relationship was observed by Kang et al. (2016) in 20 AChRAb(+) MG patients. None of previous studies tested correlation between BAFF and AChRAb levels in both immuno-suppressed and non-immuno-suppressed patients separately. Ragheb et al. (2008) included only non-immuno-suppressed patients.
Our study demonstrated significantly higher BAFF levels in female MG patients than in males. Similar trend was reported in Ragheb et al.(2008), while Kang et al. (2016) observed no differences between males and females in BAFF levels, in both studies, the M:F groups were small. There are few data about gender differences in BAFF levels in autoimmune diseases other than MG, although Panchanathan and Choubey (2013) reported that levels of the BAFF mRNA were measurably higher in cells isolated from females than male mouse models of lupus diseases and murine BAFF expression was found to be up-regulated by estrogen and interferons. In recent MG study by Deng et al. (2019), polymorphism in BAFF gene was also found to be gender-dependent: frequency of genotype AA in female MG patients was significantly elevated compared to control group. However, some studies showed no significant differences in BAFF levels between women and men with autoimmune diseases (Lin et al. 2016; Mameli et al. 2016).

Our thymoma patients had significantly lower BAFF levels than non-T-MG. T-MG patients, contrarily to the patients without thymoma, did not differ significantly in BAFF levels depending on CS therapy status. Kim et al. (2008) reported trend to higher BAFF levels in thymoma or thymic hyperplasia patients, but the observation did not reach the statistical significance. None of the other studies reported significant differences in BAFF levels between T-MG patients and non-T-MG. We have not found differences in BAFF levels depending on the history of thymectomy. This observation is consistent with Kim et al. (2008) and Scuderi et al. (2011) studies.

Although we have observed a faint negative correlation between BAFF levels and MGFA score, only recent CS treatment and male gender were found to be independent predictors of lower BAFF levels. Consistently, in several studies, there were no differences in BAFF levels related to the severity of symptoms (Guptill et al. 2015; Kang et al. 2016; Kim et al. 2008; Ragheb et al. 2008; Scuderi et al. 2011).

In conclusion, our study confirms lower BAFF serum levels in $\mathrm{AChRAb}(+)$ but also AChRAb(-)MuSK(-) MG patients treated with CS-the question whether this effect is long-term and reflected in clinical status of patient remains open. The results of studies concerning BAFF as potential target for novel drugs in MG are contradictory. Recent experimental report showed dose-dependent, immunomodulatory distant effect resulting from BAFF receptor-specific mAb-siRNA-conjugate treatment in an in vivo model of MG (Ibtehaj and Huda 2017). Though, the result of belimumab (monoclonal antibody against BAFF) study in MG, already approved for treating SLE, was negative (Dalakas 2019; Hewett et al. 2018). Therefore, we conclude that BAFF inhibition with novel drugs could be promising (Dalakas 2019; Huang et al. 2018; Nakayamada and Tanaka 2016), yet not 
well-established pathway in autoimmune diseases possibly including also myasthenia gravis.

Supplementary Information The online version contains supplementary material available at https://doi.org/10.1007/s00005-021-00626-5.

Author contributions ES primary author, study design, manuscript writing, statistical analysis, data analysis; PS data collection, data analysis, critical manuscript review; JK data collection, critical manuscript review; BS data collection, critical manuscript review; ML data collection, critical manuscript review; AKP study design, data analysis and interpretation, critical manuscript review. All authors have made substantial, direct and intellectual contribution to the work, and approved it for publication.

Funding The work was supported by NCN DEC-2011/01/B/ NZ5/05346 Grant.

Availability of data and material Yes.

\section{Declarations}

Conflict of interest None declared.

Ethics approval Study was approved by local ethics committee (KB/186/2007).

Open Access This article is licensed under a Creative Commons Attribution 4.0 International License, which permits use, sharing, adaptation, distribution and reproduction in any medium or format, as long as you give appropriate credit to the original author(s) and the source, provide a link to the Creative Commons licence, and indicate if changes were made. The images or other third party material in this article are included in the article's Creative Commons licence, unless indicated otherwise in a credit line to the material. If material is not included in the article's Creative Commons licence and your intended use is not permitted by statutory regulation or exceeds the permitted use, you will need to obtain permission directly from the copyright holder. To view a copy of this licence, visit http://creativecommons.org/licenses/by/4.0/.

\section{References}

Chen M, Lin X, Liu Y et al (2014) The function of BAFF on T helper cells in autoimmunity. Cytokine Growth Factor Rev 25:301-305. https://doi.org/10.1016/j.cytogfr.2013.12.011

Dalakas MC (2019) Immunotherapy in myasthenia gravis in the era of biologics. Nat Rev Neurol 15:113-124. https://doi.org/10.1038/ s41582-018-0110-z

Deng H, Wang J, Kong X et al (2019) Associations of BAFF rs2893321 polymorphisms with myasthenia gravis susceptibility. BMC Med Genet 20:168. https://doi.org/10.1186/s12881-019-0906-8

Ferraccioli G, Gremese E (2017) B cell activating factor (BAFF) and BAFF receptors: fakes and facts. Clin Exp Immunol 190:291-292. https://doi.org/10.1111/cei.13039

Guptill JT, Yi JS, Sanders DB et al (2015) Characterization of B cells in muscle-specific kinase antibody myasthenia gravis. Neurol Neuroimmunol Neuroinflamm 2:e77. https://doi.org/10.1212/ NXI.0000000000000077

Hewett K, Sanders DB, Grove RA et al (2018) Randomized study of adjunctive belimumab in participants with generalized myasthenia gravis. Neurology 90:e1425-e1434. https://doi.org/ 10.1212/WNL.0000000000005323

Hoch W, McConville J, Helms S et al (2001) Auto-antibodies to the receptor tyrosine kinase MuSK in patients with myasthenia gravis without acetylcholine receptor antibodies. Nat Med 7:365-368. https://doi.org/10.1038/85520

$\mathrm{Hu}$ S, Wang R, Zhang M et al (2019) BAFF promotes T cell activation through the BAFF-BAFF-R-PI3K-Akt signaling pathway. Biomed Pharmacother 114:108796. https://doi.org/10.1016/j. biopha.2019.108796

Huang W, Quach TD, Dascalu C et al (2018) Belimumab promotes negative selection of activated autoreactive B cells in systemic lupus erythematosus patients. JCI Insight 3:e122525. https:// doi.org/10.1172/jci.insight.122525

Ibtehaj N, Huda R (2017) High-dose BAFF receptor specific mAbsiRNA conjugate generates Fas-expressing B cells in lymph nodes and high-affinity serum autoantibody in a myasthenia mouse model. Clin Immunol 176:122-130. https://doi.org/10. 1016/j.clim.2017.01.005

Kalled SL (2005) The role of BAFF in immune function and implications for autoimmunity. Immunol Rev 204:43-54. https://doi. org/10.1111/j.0105-2896.2005.00219.x

Kang SY, Kang CH, Lee KH (2016) B-cell-activating factor is elevated in serum of patients with myasthenia gravis. Muscle Nerve 54:1030-1033. https://doi.org/10.1002/mus.25162

Khan WN, Wright JA, Kleiman E et al (2013) B-lymphocyte tolerance and effector function in immunity and autoimmunity. Immunol Res 57:335-353. https://doi.org/10.1007/ s12026-013-8466-Z

Kim JY, Yang Y, Moon JS et al (2008) Serum BAFF expression in patients with myasthenia gravis. J Neuroimmunol 199:151-154. https://doi.org/10.1016/j.jneuroim.2008.05.010

Kubiszewska J, Szyluk B, Szczudlik P et al (2016) Prevalence and impact of autoimmune thyroid disease on myasthenia gravis course. Brain Behav 6:e00537. https://doi.org/10.1002/brb3.537

Lahiri A, Pochard P, Le Pottier L et al (2012) The complexity of the BAFF TNF-family members: implications for autoimmunity. J Autoimmun 39:189-198. https://doi.org/10.1016/j.jaut.2012.05. 009

Lin JD, Wang YH, Fang WF et al (2016) Serum BAFF and thyroid autoantibodies in autoimmune thyroid disease. Clin Chim Acta 462:96-102. https://doi.org/10.1016/j.cca.2016.09.004

Lindstrom JM, Seybold ME, Lennon VA et al (1976) Antibody to acetylcholine receptor in myasthenia gravis. Prevalence, clinical correlates, and diagnostic value. Neurology. https://doi.org/10.1212/ wnl.26.11.1054

Mameli G, Cossu D, Caggiu E et al (2016) Soluble BAFF Level is not correlated to Mycobacterium avium subspecies paratuberculosis antibodies and increases after interferon- $\beta$ therapy in multiple sclerosis patients. J Mol Neurosci 60:91-93. https://doi.org/10. 1007/s12031-016-0787-7

Migita K, Ilyassova B, Kovzel EF et al (2010) Serum BAFF and APRIL levels in patients with PBC. Clin Immunol 134:217-225. https:// doi.org/10.1016/j.clim.2009.09.007

Moore PA, Belvedere O, Orr A et al (1999) BLyS: member of the tumor necrosis factor family and B lymphocyte stimulator. Science 285:260-263. https://doi.org/10.1126/science.285.5425.260

Nakayamada S, Tanaka Y (2016) BAFF- and APRIL-targeted therapy in systemic autoimmune diseases. Inflamm Regen 36:6. https:// doi.org/10.1186/s41232-016-0015-4

Panchanathan R, Choubey D (2013) Murine BAFF expression is upregulated by estrogen and interferons: implications for sex bias in the development of autoimmunity. Mol Immunol 53:15-23. https://doi.org/10.1016/j.molimm.2012.06.013 
Pillai S, Mattoo H, Cariappa A (2011) B cells and autoimmunity. Curr Opin Immunol 23:721-731. https://doi.org/10.1016/j.coi.2011. 10.007

Qin Q, Chang Y, Wang D et al (2011) TACI-Ig induces immune balance of Th cells in MLN via BLyS/APRIL-receptors signaling in rats with adjuvant-induced arthritis. Int Immunopharmacol 11:2167-2175. https://doi.org/10.1016/j.intimp.2011.09.014

Ragheb S, Lisak R, Lewis R et al (2008) A potential role for B-cell activating factor in the pathogenesis of autoimmune myasthenia gravis. Arch Neurol 65:1358-1362. https://doi.org/10.1001/archn eur.65.10.1358

Rauch M, Tussiwand R, Bosco N et al (2009) Crucial role for BAFFBAFF-R signaling in the survival and maintenance of mature $B$ cells. PLoS ONE 4:e5456. https://doi.org/10.1371/journal.pone. 0005456

Schneider P, MacKay F, Steiner V et al (1999) BAFF, a novel ligand of the tumor necrosis factor family, stimulates B cell growth. J Exp Med 189:1747-1756. https://doi.org/10.1084/jem.189.11.1747

Scuderi F, Alboini PE, Bartoccioni E et al (2011) BAFF serum levels in myasthenia gravis: effects of therapy. J Neurol 258:2284-2285. https://doi.org/10.1007/s00415-011-6092-z
Swee LK, Tardivel A, Schneider P et al (2010) Rescue of the mature $\mathrm{B}$ cell compartment in BAFF-deficient mice by treatment with recombinant Fc-BAFF. Immunol Lett 131:40-48. https://doi.org/ 10.1016/j.imlet.2010.03.007

Tang X, Zhang L, Wei W (2018) Roles of TRAFs in NF-кB signaling pathways mediated by BAFF. Immunol Lett 196:113-118. https:// doi.org/10.1016/j.imlet.2018.01.010

Thangarajh M, Masterman T, Helgeland L et al (2006) The thymus is a source of B-cell-survival factors-APRIL and BAFF-in myasthenia gravis. J Neuroimmunol 178:161-166. https://doi.org/10.1016/j. jneuroim.2006.05.023

Vannucchi G, Covelli D, Currò N et al (2012) Serum BAFF concentrations in patients with Graves' disease and orbitopathy before and after immunosuppressive therapy. J Clin Endocrinol Metab 97:E755-759. https://doi.org/10.1210/jc.2011-2614

Publisher's Note Springer Nature remains neutral with regard to jurisdictional claims in published maps and institutional affiliations. 